\title{
Tarif Pelayanan Pembedahan Katarak Pasien Jaminan Kesehatan Nasional dengan Teknik Fakoemulsifikasi dan Small Incision Cataract Surgery
}

\section{Cataract Surgery of Phacoemulsification and Small Incision Cataract Surgery Tariff for National Health Insurance Patients}

\author{
Riris D. Hardiani ${ }^{1}$, Tris Eryando ${ }^{1}$ \\ 1) Departemen Biostatistik dan Kependudukan, Fakultas Kesehatan Masyarakat, Universitas Indonesia, Jalan Lingkar \\ Kampus Raya, Depok, Jawa Barat 16424, Indonesia \\ Korespondensi: ririsdian@yahoo.com
}

Submitted: 20 September 2019, Revised: 13 Desember 2019, Accepted: 24 Desember 2019

https://doi.org/10.22435/jpppk.v3i3.2659

\begin{abstract}
Abstrak
Prevalensi kebutaan di Indonesia karena katarak pada penduduk berusia $\geq 50$ tahun sebesar 3\% dan salah satu biaya kesehatan terbesar di tahun 2017 adalah untuk pembedahan katarak. Untuk melakukan pembandingan tarif rumah sakit serta tarif Indonesian Case Base Groups (INA-CBG) pelayanan pembedahan katarak dengan teknik fakoemulsifikasi dan Small Incision Cataract Surgery (SICS) dilakukan penelitian potong lintang menggunakan data klaim Jaminan Kesehatan Nasional (JKN) Rumah Sakit "X". Perbedaan tarif fakoemulsifikasi dan SICS dianalisis secara bivariat dengan Mann-Whitney. Dari 1278 pasien katarak, terbanyak adalah pasien laki laki, berumur $\geq 60$ tahun, 84,7\% pembedahan menggunakan teknik fakoemulsifikasi, dan $77,2 \%$ pembedahan dilakukan di rawat jalan. Untuk pelayanan rawat inap, fakoemulsifikasi terbanyak di ruang perawatan kelas 1 (50,0\%) dan SICS di kelas 3 (65,4\%). Rerata tarif rumah sakit untuk rawat jalan fakoemulsifikasi $R p$ 9.536.041,- $\pm 1.336 .734,03$ dan SICS adalah Rp 7.438.924,$\pm 1.160 .666,63(p<0,05)$ sedangkan untuk rawat inap fakoemulsfikasi $R p$ 9.355.253,- $\pm 2.288 .647,36$ dan SICS Rp 6.078.391,- $\pm 1.854 .308,65$ ( $p<0,05$ ). Rerata tarif INA-CBG fakoemulsifikasi rawat jalan adalah Rp 8.809.191,- $\pm 218.193,55$ dan SICS Rp 4.410.000 $(p<0,05)$ sedangkan untuk rawat inap fakoemulsfikasi $R p$ 10.834.039,- $\pm 2.019 .676,19$ dan SICS Rp 9.074.188 $\pm 1.638 .329,7$ ( $p<0,05)$. Rerata tarif rumah sakit dan tarif INA-CBG untuk teknik pembedahan katarak dengan SICS baik rawat jalan maupun rawat inap lebih rendah dibandingkan dengan teknik fakoemulsifikasi. Tarif INA-CBG yang dibayarkan Badan Penyelenggara Jaminan Sosial (BPJS) Kesehatan untuk kedua metode pembedahan katarak pada pelayanan rawat jalan lebih rendah sedangkan untuk rawat inap lebih tinggi dibandingkan dengan tarif rumah sakit.
\end{abstract}

Kata kunci: Fakoemulsifikasi, SICS, Katarak, JKN

\section{Abstract}

The prevalence of blindness in Indonesia due to cataracts in the population aged 50 years and above is $3 \%$. However, one of the highest health costs in 2017 was on cataract surgery. To compare hospital tariff and Indonesian Case Base Groups (INA-CBG) tariff of phacoemulsification and Small Incision Cataract Surgery (SICS), a cross-sectional study was conducted using National Health Insurance claim data at Hospital "X". The differences between phacoemulsification and SICS tariff were analyzed using the Mann-Whitney test. From a total of 1278 patients, majority were males, aged 60 years and above. $84.7 \%$ of the patients went through a phacoemulsification procedure, $77.2 \%$ were outpatients. Most inpatients that went through a phacoemulsification were admitted to class 1 wards (50.0\%) while a majority of those went through a SICS procedure were admitted to class 3 wards (65.4\%). There were significant differences in the average hospital tariff 
between phacoemulsification and SICS for both outpatients' (IDR 9,536,041 $\pm 1,336,734.03$ vs IDR 7,438, 924 $\pm 1,160,666.63 ; p<0.05$ ) and inpatients' (IDR 9,355,253 $\pm 2,288,647.36$ vs IDR 6,078,391 $\pm 1,854,308.65$; $p<0.05$ ) care. The average INA-CBG tariff also had significant differences between both procedures for outpatients' care (phacoemulsification vs SICS: IDR 8,809, $191 \pm 218,193.55$ vs IDR 4,410,000; $p<0.05$ ) and inpatients' care (IDR 10,834,039 $\pm 2,019,676.19$ vs IDR 9,074,188 $\pm 1,638,329.7 ; p<0.05)$. The average hospital and INA-CBG tariff of SICS, for both outpatients and inpatients were lower than that of phacoemulsification. Although INACBG tariffs paid by the Social Insurance Administration Organization for Health or BPJS Kesehatan for both phacoemulsification and SICS procedures in outpatients was lower, the INA-CBG inpatients' tariff was higher than the hospital tariff.

Keywords: Phacoemulsification, SCIS, Cataracts, National Health Insurance (NHI)

\section{Pendahuluan}

Menurut World Health Organization sekitar 20 juta orang (2010) atau 51\% kebutaan di dunia disebabkan oleh katarak. Di Asia Tenggara prevalensi kebutaan pada usia lebih dari 30 tahun lebih tinggi terjadi di Bangladesh, Indonesia, dan di beberapa negara bagian di India sedangkan yang terendah terjadi di Thailand dan Sri Lanka. ${ }^{1}$ Survei kebutaan Rapid Assessment of Avoidable Blindness (RAAB) yang dilakukan oleh Persatuan Dokter Spesialis Mata Indonesia (PERDAMI) dan Badan Litbangkes tahun 2014-2016 di 15 provinsi pada penduduk berusia $\geq 50$ tahun menunjukkan prevalensi kebutaan sebesar 3\% dengan katarak sebagai penyebab utama. Katarak adalah kekeruhan lensa yang menyebabkan penurunan ketajaman visual dan/atau cacat fungsional yang dirasakan oleh pasien. Katarak dapat memiliki derajat kepadatan (density) yang sangat bervariasi dan dapat disebabkan oleh berbagai hal, namun umumnya disebabkan oleh proses degeneratif. ${ }^{2}$ Seiring dengan peningkatan usia harapan hidup penduduk Indonesia akan berdampak pada peningkatan kasus katarak.

Tatalaksana katarak adalah dengan tindakan pembedahan. Ada beberapa jenis pembedahan katarak yaitu Intra Capsular Cataract Extraction (ICCE), Extra Capsular Cataract Extraction (ECCE), Small Incision Cataract Surgery (SICS), dan fakoemulsifikasi. Hadirnya teknik fakoemulsifikasi serta foldable Intraocular Lens (IOL) telah menggeser paradigma tatalaksana katarak menuju ke teknik terbaik yang paling aman. $^{2}$ Namun teknik pembedahan dengan fakoemulsifikasi membutuhkan biaya yang tinggi karena mesin fakoemulsifikasi mahal, memiliki biaya pakai yang relatif tinggi, dan membutuhkan pelatihan pembedahan. ${ }^{3}$ Rekomendasi yang diberikan PERDAMI untuk pembedahan kasus katarak adalah dengan teknik ekstrakapsular, baik menggunakan mesin (fakoemulsifikasi) atau manual yang memberikan rehabilitasi visual paling baik dan komplikasi yang minimal. Katarak dengan teknik small incision memberikan hasil yang lebih baik. Katarak dengan derajat awal yang dilakukan dengan teknik small incision akan menurunkan kemungkinan terjadinya komplikasi. ${ }^{2}$

Fakoemulsifikasi adalah tindakan menghancurkan lensa mata menjadi bentuk yang lebih lunak, sehingga mudah dikeluarkan melalui luka yang lebih kecil (2-3 mm) dengan menggunakan mesin fakoemulsifikasi. SICS merupakan pembedahan katarak manual dengan luka insisi yang lebih kecil dibandingkan ECCE. Luka insisi pada SICS dibuat lebih ke arah sklera dan dengan membuat terowongan (tunnel) dari sklera ke kornea untuk kemudian menembus bilik mata depan. Luka insisi yang lebih kecil sebesar 6-9 mm dan tunnel berukuran $4 \mathrm{~mm}$ menyebabkan luka menjadi kedap meskipun tanpa jahitan, sehingga dapat menurunkan risiko astigmatisma pasca pembedahan. ${ }^{2}$ Untuk negara berkembang dengan jumlah pasien yang banyak dan sumber daya yang terbatas teknik SICS adalah teknik pengobatan katarak yang paling tepat. ${ }^{4,5}$

Di banyak negara berkembang, kebutaan karena katarak disebabkan karena kurangnya akses untuk pembedahan mata. ${ }^{6}$ Di Indonesia sejak diluncurkan program Jaminan Kesehatan Nasional (JKN) pada 1 Januari 2014, jumlah kunjungan ke fasilitas kesehatan terus meningkat. Pembedahan katarak merupakan pelayanan yang ditanggung dalam program JKN. Data dari Badan Penyelenggara Jaminan Sosial (BPJS) Kesehatan sebagai penyelenggara program JKN menyebutkan 
jumlah kasus pembedahan katarak pada tahun 2017 sebanyak 79.498 kasus rawat inap dan 297.029 kasus rawat jalan. Teknik pembedahan katarak terbanyak yang digunakan adalah fakoemulsifikasi. Salah satu biaya kesehatan terbesar pada tahun 2017 menurut BPJS Kesehatan adalah untuk pembedahan katarak yakni Rp 2,65 triliun. ${ }^{7}$ Biaya ini jauh lebih tinggi dari biaya untuk kasus katastropik seperti gagal ginjal kronis yang berjumlah Rp 2,3 triliun. ${ }^{8}$ Pembayaran pembedahan katarak ke rumah sakit sesuai dengan tarif Indonesian Case Based Groups (INA-CBG). ${ }^{9}$ Permasalahan dalam pembiayaan kesehatan akan berimplikasi terhadap penyediaan pelayanan kesehatan. Untuk menjamin kesinambungan program JKN, selain mutu layanan yang diberikan kepada pasien katarak, fasilitas kesehatan juga harus mempertimbangkan efektivitas dan efisiensi.

Berdasarkan hal tersebut di atas perlu dilakukan penelitian untuk mengetahuiperbandingan tarif fakoemulsifikasi dan SICS serta tarif INACBG yang dibayarkan oleh BPJS Kesehatan. Studi ini merupakan bahan awal untuk melakukan analisis efektivitas biaya pelayanan pembedahan katarak.

\section{Metode}

Penelitian ini adalah penelitian potong lintang untuk membandingkan tarif pembedahan katarak antara teknik Fakoemulsifikasi dengan teknik SICS. Data tarif didapatkan dari data sekunder yaitu data klaim rumah sakit "X". Populasi penelitian ini adalah semua pasien JKN pada bulan Januari-Agustus tahun 2018 dengan diagnosis utama katarak senilis atau katarak lainnya dengan kode ICD-10: H25.0, H25.1, H25.2, H25.8, H25.9, H26.0, H26.1, H26.2, dan H26.3 yang dilakukan prosedur fakoemulsifikasi (kode ICD-9 CM 13.41) atau prosedur SCIS (kode ICD-9 CM 13.59). Besar sampel yang digunakan adalah seluruh populasi yakni sebanyak 1278 pasien.

Variabel yang digunakan dalam penelitian ini adalah jenis kelamin, umur, jenis perawatan, kelas perawatan untuk pasien rawat inap, lama rawat, tarif INA-CBG, dan tarif rumah sakit. Untuk komponen tarif rumah sakit terdiri dari tarif prosedur bedah, konsultasi, penunjang, keperawatan, laboratorium, akomodasi, obat, bahan medis habis pakai. Pemilihan jenis variabel yang diteliti dilakukan berdasarkan penelitian terdahulu yang dilakukan oleh Budiarto dan Sugiarto (2013) dan Sari RP (2013). ${ }^{10,11}$

Analisis data dalam penelitian ini adalah analisis univariat dan bivariat dengan MannWhitney yang bertujuan untuk mengetahui rerata tarif pembedahan katarak, rerata tarif INA-CBG yang dibayarkan BPJS Kesehatan dan rerata lama rawat antara teknik yang banyak digunakan saat ini yaitu fakoemulsifikasi dan teknik alternatif yakni SICS pada pasien JKN. Analisis data dilakukan dengan bantuan perangkat lunak Statistical Package for the Social Sciences (SPSS).

\section{Hasil}

Hasil analisis univariat data klaim rumah sakit "X" (Tabel 1) didapatkan dari 1278 pasien, jumlah pasien katarak yang dilakukan prosedur fakoemulsfikasi sebanyak $1082(84,7 \%)$ dan yang dilakukan SICS sebanyak 196 (15,3\%). Proporsi pasien katarak laki laki lebih banyak dari pasien perempuan baik untuk teknik Fakoemulsifikasi $(55,0 \%)$ maupun untuk teknik SICS $(60,7 \%)$ dan berumur $\geq 60$ tahun yakni 53,5\% untuk teknik fakoemulsifikasi dan 60,2\% untuk teknik SICS. Prosedur pembedahan katarak terbanyak dilakukan di rawat jalan 986 pasien $(77,2 \%)$ dengan proporsi $75,4 \%$ untuk teknik fakoemulsifikasi dan $86,7 \%$ untuk teknik SICS. Proporsi pasien yang menjalani rawat inap dengan teknik fakoemulsifikasi terbanyak di kelas $1(50,0 \%)$ sedangkan untuk pasien dengan teknik SICS pasien dirawat terbanyak di kelas 3 $(65,4 \%)$.

Hasil analisis bivariat untuk pembedahan yang dilaksanakan di rawat jalan terlihat pada Tabel 2. Rerata tarif merupakan hasil bagi dari total jumlah tarif masing-masing komponen tarif rawat jalan dibagi dengan jumlah pasien. Rerata tarif rumah sakit untuk Fakoemulsifikasi adalah Rp 9.536.041 sedangkan rerata tarif untuk SICS adalah Rp 7.438 .924 ( $p<0,05)$. Jika tarif rumah sakit diuraikan berdasarkan komponen tarif yakni prosedur bedah, obat, dan bahas habis pakai juga didapatkan rerata tarif yang lebih tinggi pada teknik Fakoemulsfikasi dibanding teknik SICS $(p<0,05)$. Tidak terdapat perbedaan yang signifikan untuk rerata tarif komponen konsultasi untuk kedua teknik pembedahan. Rerata tarif INA-CBG yang dibayarkan ke rumah sakit oleh BPJS Kesehatan adalah Rp 8.809.191,- untuk teknik fakoemulsfikasi 
Tabel 1. Karakteristik Pasien Senile berdasarkan Jenis Pembedahan yang Dilakukan

\begin{tabular}{lcccccc}
\hline \multicolumn{1}{c}{ Karakteristik Pasien } & \multicolumn{2}{c}{ Fakoemulsifikasi } & \multicolumn{2}{c}{ SICS* } & \multicolumn{2}{c}{ Total } \\
\cline { 2 - 7 } & $\mathbf{n}$ & $\mathbf{\%}$ & $\mathbf{n}$ & $\mathbf{\%}$ & $\mathbf{n}$ & $\mathbf{\%}$ \\
\hline $\begin{array}{l}\text { Jenis Pembedahan } \\
\text { Jenis Kelamin }\end{array}$ & 1082 & 84.7 & 196 & 15.3 & 1278 & $100.0 \%$ \\
$\quad$ Laki-Laki & & & & & & \\
$\quad$ Perempuan & 595 & 55.0 & 119 & 60.7 & 714 & 55.9 \\
Umur & 487 & 45.0 & 77 & 39.3 & 564 & 44.1 \\
$\quad<60$ tahun & & & & & & \\
$\quad \geq 60$ tahun & 503 & 46.5 & 78 & 39.8 & 581 & 45.5 \\
Jenis Layanan & 579 & 53.5 & 118 & 60.2 & 697 & 54.5 \\
$\quad$ Rawat Jalan & & & & & & \\
$\quad$ Rawat Inap & 816 & 75.4 & 170 & 86.7 & 986 & 77.2 \\
Kelas Perawatan (Rawat Inap) & 266 & 24.6 & 26 & 13.3 & 292 & 22.8 \\
$\quad$ 1 & 133 & 50.0 & 6 & 23.1 & 139 & 47.6 \\
$\quad 2$ & 54 & 20.3 & 3 & 11.5 & 57 & 19.5 \\
$\quad 3$ & 79 & 29.7 & 17 & 65.4 & 96 & 32.9 \\
\hline
\end{tabular}

*SICS: Small Incision Cataract Surgery

Tabel 2. Rerata Tarif Rawat Jalan berdasarkan Jenis Pembedahan yang Dilakukan

\begin{tabular}{llllll}
\hline \multirow{2}{*}{ Jenis Biaya (Tarif) } & \multicolumn{3}{c}{ Fakoemulsifikasi } & \multicolumn{3}{c}{ SICS } & \multirow{2}{*}{ Nilai p } \\
\cline { 2 - 5 } & $\begin{array}{c}\text { Rerata Tarif } \\
\mathbf{( R p )}\end{array}$ & \multicolumn{1}{c}{ SD } & \multicolumn{1}{c}{$\begin{array}{c}\text { Rerata Tarif } \\
(\mathbf{R p})\end{array}$} & \multicolumn{1}{c}{ SD } & \\
\hline Total Tarif Rumah Sakit & 9.536 .041 & $1.336 .734,03$ & 7.438 .924 & $1.160 .666,63$ & $\mathrm{p}<0,001$ \\
$\quad$ Prosedur Bedah & 8.523 .024 & $1.292 .395,75$ & 6.671 .914 & $757.486,34$ & $\mathrm{p}<0,001$ \\
Konsultasi & 389.286 & $358.848,69$ & 372.621 & $75.791,67$ & 0,863 \\
Obat & 155.778 & $145.142,03$ & 149.001 & $27.469,12$ & 0,010 \\
Bahan Medis Habis Pakai & 452.326 & $716.160,64$ & 232.736 & $837.535,59$ & $\mathrm{p}<0,001$ \\
Tarif INA-CBG & 8.809 .191 & $218.193,55$ & 4.410 .000 & 0 & $\mathrm{p}<0,001$ \\
\hline
\end{tabular}

*SICS: Small Incision Cataract Surgery

INA-CBG: Indonesian Case Base Groups

dan Rp 4.410.000,- untuk teknik SICS ( $<<0,05)$.

Untuk pembedahan katarak yang dilakukan di rawat inap terlihat pada Tabel 3. Rerata tarif pada Tabel 3 merupakan hasil bagi dari total jumlah tarif masing-masing komponen tarif di rawat inap dibagi dengan jumlah pasien. Rerata tarif rumah sakit pada teknik fakoemulsfikasi adalah $\mathrm{Rp} 9.355 .253$,- dan rerata tarif untuk SICS Rp 6.078.391,- $(\mathrm{p}<0,05)$. Jika tarif rumah sakit diuraikan berdasarkan komponen tarif rawat inap yakni prosedur bedah, konsultasi, laboratorium, akomodasi (kamar), dan bahan habis pakai, rerata tarif pada teknik fakoemulsifikasi lebih tinggi dibanding teknik SICS $(\mathrm{p}<0,05)$. Sedangkan untuk komponen tarif keperawatan dan penunjang pada teknik fakoemulsifikasi lebih rendah, namun tidak ditemukan perbedaan secara statistik $(\mathrm{p}>0,05)$. Untuk rerata tarif INA-CBG yang dibayarkan oleh BPJS Kesehatan ke rumah sakit adalah $\mathrm{Rp}$ 10.834.039,- untuk teknik Fakoemulsfikasi dan untuk teknik SICS Rp 9.074.188,- $(\mathrm{p}<0,05)$.

Rerata lama hari rawat (Tabel 4) untuk kedua teknik pembedahan katarak ini hampir sama yakni 2 hari dan secara statistik tidak ada perbedaan yang signifikan $(\mathrm{p}>0,05)$. 
Tabel 3 Rerata Tarif Rawat Inap berdasarkan Jenis Pembedahan yang Dilakukan

\begin{tabular}{|c|c|c|c|c|c|}
\hline \multirow{2}{*}{ Jenis Biaya (Tarif) } & \multirow{2}{*}{$\begin{array}{l}\text { Fakoemulsifikasi } \\
\text { Rerata Tarif (Rp) }\end{array}$} & \multicolumn{3}{|c|}{ SICS } & \multirow{2}{*}{ Nilai p } \\
\hline & & SD & Rerata Tarif (Rp) & SD & \\
\hline Total Tarif Rumah Sakit & 9.355 .253 & $2.288 .647,36$ & 6.078 .391 & $1.854 .308,65$ & $\mathrm{p}<0,001$ \\
\hline Prosedur Bedah & 7.907.297 & $1.851 .675,67$ & 5.215 .204 & $1.165 .454,67$ & $\mathrm{p}<0,001$ \\
\hline Konsultasi & 97.784 & $425.283,82$ & 52.038 & $31.843,97$ & 0,010 \\
\hline Keperawatan & 20.135 & $17.810,86$ & 21.308 & $19.850,98$ & 0,444 \\
\hline Penunjang & 11.579 & $53.355,51$ & 10.308 & $52.559,12$ & 0,518 \\
\hline Laboratorium & 38.466 & $81.118,51$ & 14.615 & $44.382,95$ & 0,033 \\
\hline Akomodasi (Kamar) & 415.526 & $250.520,79$ & 322.692 & $320.256,87$ & 0,006 \\
\hline Obat & 166.687 & $64.373,26$ & 177.054 & $79.539,38$ & 0,101 \\
\hline Bahan Medis Habis Pakai & 697.778 & $842.781,61$ & 265.171 & $679.225,88$ & $\mathrm{p}<0,001$ \\
\hline Tarif INA CBG & 10.834 .039 & $2.019 .676,19$ & 9.074 .188 & $1.638 .329,78$ & $\mathrm{p}<0,001$ \\
\hline
\end{tabular}

*SICS: Small Incision Cataract Surgery

INA CBG: Indonesian Case Base Group

Tabel 4 Rerata Lama Rawat berdasarkan Jenis Pembedahan yang dilakukan

\begin{tabular}{lccc}
\hline $\begin{array}{c}\text { Jenis } \\
\text { Pembedahan }\end{array}$ & $\begin{array}{c}\text { Rerata Lama } \\
\text { Rawat }\end{array}$ & SD & $\begin{array}{c}\text { P } \\
\text { value }\end{array}$ \\
\hline Fakoemulsifikasi & 2,47 & 0,5 & 0,602 \\
SICS & 2,58 & 0,7 & \\
\hline
\end{tabular}

\section{Pembahasan}

Studi ini berhasil mengumpulkan data dari 1278 pasien katarak yang menjalani prosedur Fakoemulsifikasi dan SICS. Data yang dikumpulkan meliputi demografi pasien, jenis pelayanan, lama rawat, tarif rumah sakit, dan tarif INA CBG. Pemilihan variabel dalam studi ini mengacu pada penelitian sebelumnya yang melakukan perbandingan tarif rumah sakit dan tarif INACBG. ${ }^{10,11}$

Temuan dari studi ini, pasien katarak yang menjalani pembedahan terbanyak pada laki-laki. Hal ini sesuai dengan hasil dari tinjauan pustaka dan meta-analisis katarak di negara-negara berkembang, ditemukan bahwa cakupan pembedahan katarak 1,2-1,7 kali lebih tinggi untuk laki-laki daripada perempuan. Odds ratio perempuan untuk menjalani pembedahan katarak dibandingkan dengan laki-laki dalam meta-analisis ini adalah 0,67 (95\% CI: 0,60$0,74)(12)$. Secara global, perempuan mengalami tingkat kebutaan lebih tinggi dibandingkan dengan laki-laki, yakni $64,5 \%$ dari semua kebutaan. ${ }^{13}$

Dari studi ini ditemukan lebih dari separuh pasien berusia 60 tahun ke atas. Di Amerika Serikat, sebagian besar kejadian katarak terkait usia, terjadi pada lebih dari separuh orang Amerika yang berusia lebih dari 65 tahun. Dalam banyak kasus, katarak muncul pertama kali ketika seseorang berusia sekitar 40 atau 50 tahun, tetapi belum memengaruhi penglihatannya, sampai setelah usia 60 tahun baru kebutaan mulai terjadi. ${ }^{14}$

Sebanyak $77,2 \%$ pembedahan katarak dilakukan di rawat jalan. Pembedahan katarak dilakukan di rawat jalan karena pembedahan katarak adalah prosedur bedah yang aman dan umum dilakukan. ${ }^{15}$ Dari sudut pandang medis, ekstraksi katarak modern tidak mensyaratkan perawatan semalam di rumah sakit. Namun, dalam kasus tertentu (misalnya, setelah anestesi umum atau pasien dengan komorbiditas berat termasuk gangguan mental), memerlukan pembedahan dilakukan di rawat inap. Transisi pembedahan katarak dari rawat inap ke rawat jalan sudah mulai dilakukan di banyak negara sekitar tahun 1980 -an. ${ }^{16}$ Di Amerika Serikat sejak tahun 1985 diberlakukan aturan pembedahan katarak yang dijamin oleh Medicare harus dilakukan di rawat jalan. ${ }^{17}$ Di negara maju pembedahan mata dilakukan di rawat jalan kecuali untuk pembedahan orbital dan kondisi sistemik langka yang jarang. 
Dengan melakukan pembedahan mata di rawat jalan akan memperpendek waktu tunggu, biaya yang lebih rendah, lama waktu di rumah sakit yang lebih singkat, dan mengurangi investasi dalam fasilitas medis dan personil, komplikasi pasca pembedahan lebih rendah, prognosis visual yang lebih baik dan dipatuhi pasien. ${ }^{18}$

Studi yang dilakukan Holland et al. ${ }^{19}$ 1992 menunjukkan bahwa tidak ada perbedaan tajam penglihatan dan angka komplikasi pasca pembedahan antara pasien ekstraksi katarak di rawat jalan dan rawat inap. Studi randomized controlled trial (RCT) yang dilakukan pada pasien pembedahan katarak di tiga rumah sakit umum di Barcelona menyebutkan tidak ada perbedaan yang signifikan secara statistik antara pasien rawat jalan dan rawat inap dalam hal ketajaman visual $(\mathrm{p}=$ 0,48 ), atau outcome klinis lainnya, kecuali untuk komplikasi awal pasca pembedahan. Pasien rawat jalan menunjukkan setidaknya satu komplikasi dalam 24 jam pertama setelah pembedahan, lebih sering dibandingkan pasien rawat inap (64 vs 43; RR 1,6, 95\% CI 1,1-2,4). Tetapi empat bulan setelah pembedahan tidak ada perbedaan tingkat komplikasi antara kelompok. ${ }^{20}$

Pembedahan katarak adalah salah satu prosedur bedah yang paling umum dilakukan di Eropa di mana komplikasi sangat jarang terjadi dan sebagian besar dilakukan di rawat jalan. Beberapa peneliti menyatakan tidak ada perbedaan yang signifikan dalam hasil, kepuasan pasien atau risiko komplikasi pasca pembedahan antara pembedahan katarak rawat inap dan rawat jalan. ${ }^{16}$ Hasil studi yang dilakukan Mojon et.al menggunakan data survey SHARE (Survey of Health, Ageing and Retirement in Europe) tahun 2004 menunjukkan angka (rate) pembedahan katarak rawat jalan di sepuluh negara Eropa terutama dipengaruhi oleh kepadatan ruang perawatan akut (acute-care beds density), jumlah dokter di populasi (physician density) dan belanja kesehatan public. ${ }^{21}$ Selain itu studi yang dilakukan di 20 negara Eropa selama periode 2004-2014 menunjukkan rasio pembedahan katarak rawat jalan dibandingkan rawat inap meningkat signifikan menjadi 31,7 pada $2014(\mathrm{~b}=3,3, \mathrm{p}<0.001,95 \% \mathrm{CI}$ $=2,5,-4,0){ }^{22}$

Selain itu waktu yang dibutuhkan untuk melakukan pembedahan katarak juga cukup singkat. Studi yang dilakukan oleh Mahajan et.al menyebutkan rerata waktu yang dibutuhkan untuk melakukan SICS adalah 11,5 menit dan 13,2 menit untuk fakoemulsifikasi. ${ }^{23}$ Hal ini sejalan dengan studi yang dilakukan Singh SK et al. ${ }^{24}$ bahwa rerata waktu yang dibutuhkan untuk pembedahan SICS adalah 5 menit 18 detik dan untuk Fakoemulsifikasi dibutuhkan waktu 7 menit. Sementara studi yang dilakukan Khan A et al. 2015 menyatakan rerata waktu pembedahan Fakomeulsfikasi 45,35 menit $(\mathrm{SD}=6,9)$ dan SICS 34,77 (SD =6.98) menit .

Tarif rumah sakit " $X$ " untuk pelayanan pembedahan katarak rawat jalan baik dengan teknik fakoemulsifikasi maupun SICS lebih tinggi dari tarif pelayanan rawat inap (Tabel 3 dan 4). Hal ini berbeda dengan studi yang dilakukan Castells et.al ${ }^{20}$ yang menyatakan biaya pembedahan katarak lebih rendah untuk pasien rawat jalan dibandingkan pasien rawat inap (1001 vs 1218 Euro; $P<0,001$ ). Penghematan biaya jika pembedahan katarak dilakukan di rawat jalan sekitar $20 \% .^{21}$

Dari analisis bivariat didapatkan bahwa rerata tarif rumah sakit untuk teknik pembedahan katarak dengan SICS baik rawat jalan maupun rawat inap lebih rendah dibandingkan dengan teknik Fakoemulsifikasi. Studi ini sejalan dengan penelitian yang dilakukan Zatila 2008, bahwa biaya rerata pembedahan katarak pada teknik SICS lebih rendah yakni Rp 1.895.019,- dan biaya untuk Fakoemulsifikasi Rp 3.201.416,-. Biaya bahan medis habis pakai dengan teknik SICS adalah $46 \%$ dari total biaya sedangkan untuk Fakoemulsifikasi adalah $63 \%$ dari total biaya. ${ }^{25}$

Jongsareejit et al. $^{3} 2012$ melakukan penelitian untuk membandingkan biaya dan efektivitas teknik dua pembedahan katarak, SICS dan fakoemulsifikasi, menggunakan perspektif rumah sakit. Penelitian dilakukan di departemen oftalmologi, rumah sakit Phrapokklao, Thailand. Dari hasil penelitian didapatkan rerata biaya per kasus untuk teknik SICS adalah 10.043,81 bath dan 11.590,72 bath untuk kasus Fakoemulsifikasi. Studi yang dilakukan di Nepal oleh Ruit et al. ${ }^{5}$ 2007 menyimpulkan bahwa biaya operasi katarak dengan teknik SICS secara signifikan lebih murah, dibandingkan dengan Fakoemulsifikasi.

Dari hasil analisis didapatkan rerata tarif INA-CBG dengan teknik fakoemulsifikasi lebih 
tinggi dibandingkan dengan teknik SICS. Tarif INACBG untuk rawat jalan lebih rendah dibandingkan dengan tarif rumah sakit, sedangkan untuk rawat inap lebih tinggi dibandingkan dengan tarif rumah sakit. Hal ini sejalan dengan hasil penelitian yang dilakukan di rumah sakit umum di Bukittinggi tahun 2016 yang menghitung biaya tindakan operasi katarak dengan metode activity based costing. Biaya satuan untuk tindakan fakoemulsifikasi tanpa penyulit sebesar $\mathrm{Rp} 6.446 .865,86$ sedangkan tarif INA-CBG untuk tindakan fakoemulsifikasi tanpa penyulit adalah Rp. 7.456.400,00. Sehingga tarif INA-CBG yang dibayarkan oleh BPJS Kesehatan lebih tinggi sebesar Rp. 1.009.534,14 dibandingkan biaya rumah sakit. ${ }^{26}$

Penelitian yang dilakukan di Rumah Sakit Khusus Mata Provinsi Sumatera Selatan tahun 2018 pada pasien pembedahan katarak rawat inap peserta JKN menyebutkan total biaya riil pasien di rumah sakit ternyata lebih kecil dibandingkan total tarif INA-CBG. Selisih total biaya riil rumah sakit dengan INA-CBG untuk kelas rawat inap I sebesar (+Rp385.000.805), kelas rawat inap II sebesar (+Rp262.299.525), dan kelas rawat inap III sebesar (+Rp538.233.016) dari tarif INA-CBG. Terdapat hubungan yang kuat antara komponen biaya pembedahan katarak yaitu usia, lama perawatan, biaya prosedur, biaya kamar/akomodasi, visite dokter/konsultasi serta obat-obatan dengan biaya riil pasien pembedahan katarak yang ditunjukkan dengan nilai $\mathrm{p}=0,0001, \mathrm{r}=0.912 .{ }^{27}$

Studi ini menunjukkan dari sisi biaya pelayanan, teknik SICS lebih murah dibandingkan dengan teknik fakoemulsifikasi. Namun studi ini memiliki keterbatasan karena tidak dapat menilai perbandingan visus pasca pembedahan antara pembedahan katarak dengan teknik fakoemulsifikasi dan SICS. Dari beberapa studi yang dilakukan di beberapa negara menunjukkan bahwa fakoemulsifikasi dan SICS adalah teknik yang aman dan efektif untuk merehabilitasi pasien katarak dan biaya untuk teknik SICS lebih murah. . $28,29^{2}$

Baik fakoemulsifikasi maupun SICS mencapai hasil visual yang sangat baik. Pada umumnya perbaikan fungsi penglihatan (visus) post pembedahan katarak dilakukan pada hari pertama pasca pembedahan, minggu ke-1 sampai dengan minggu ke-2, 1 bulan dan 3 bulan setelah pembedahan. Studi yang dilakukan oleh Singh SK et al. ${ }^{24}$ 2009, Jongsareejit et al. ${ }^{3}$ 2012, Khanna RC et al. ${ }^{30}$ 2012, Zhang et al. ${ }^{31}$ 2013, Nanta AM $^{32}$ 2013, El-Sayed SH et al. ${ }^{4} 2015$ menyatakan bahwa tidak ada perbedaan signifikan pada hasil visual pasca pembedahan baik pada teknik fakoemulsifikasi maupun SICS.

Walaupun tidak ada perbedaan visus pasca pembedahan perlu dipertimbangkan masalah komplikasi yang terjadi pada kedua teknik ini. Studi RCT yang dilakukan Ruit et al. ${ }^{5} 2007$ menyimpulkan bahwa baik fakoemulsifikasi dan SICS mencapai hasil visual yang sangat baik dengan tingkat komplikasi yang rendah. Sementara Jongsareejit et al. $^{3} 2012$ menyatakan bahwa komplikasi intraoperatif pada kelompok fakoemulsifikasi adalah vitreus loss $(1,40 \%)$ sedangkan komplikasi pasca pembedahan pada kelompok SICS adalah edema kornea $(5,60 \%)$. Tidak ada perbedaan yang signifikan secara statistik dalam jumlah komplikasi pasca pembedahan pada kedua kelompok $(p=0,16)$. Khanna RC et al. ${ }^{30} 2012$ menyimpulkan bahwa meskipun tingkat komplikasi lebih tinggi pada kelompok SICS, tidak ada perbedaan dalam BCVA (best corrected visual acuity) pada kedua kelompok. Zhang et al. ${ }^{31} 2013$ menyatakan bahwa fakoemulsifikasi lebih unggul dari SICS dalam hal UCVA (uncorrected visual acuity) dan menyebabkan lebih sedikit surgically induced astigmatism (SIA), tetapi tidak ada perbedaan yang signifikan dalam rehabilitasi visual, kehilangan Endothelial Cell Count (ECC) dan tingkat komplikasi antara kedua teknik. Studi yang dilakukan Haripriya et al. ${ }^{33}$ 2012 menyatakan bahwa teknik SICS merupakan prosedur awal yang lebih aman untuk belajar bagi ahli bedah katarak yang tidak berpengalaman di negara berkembang. Hal ini dikarenakan terjadi komplikasi yang tinggi pada teknik fakoemulsifikasi apabila dilakukan oleh trainee.

Jaggernath et al. ${ }^{29} 2013$ melakukan tinjauan pustaka sistematis dengan tujuan untuk membandingkan keamanan, efikasi, dan efektivitas biaya pembedahan katarak dengan teknik SICS dan fakoemulsifikasi sebagai pilihan pembedahan katarak dengan fokus pada intumesensi lensa, matur, dan hipermatur (white cataract). Dari 42 manuskrip, didapatkan bahwa fakoemulsifikasi dan SICS adalah teknik yang aman dan efektif untuk merehabilitasi 
pasien katarak, namun fakoemulsifikasi lebih mahal. Studi ini menyimpulkan bahwa SICS lebih bermanfaat untuk intumesensi dan hard katarak. SICS merupakan teknik yang cocok apabila memiliki sumber daya terbatas. SICS sebanding dengan fakoemulsifikasi di hampir semua aspek kecuali astigmatisme pasca pembedahan.

Khan A et al. ${ }^{28} 2015$ melakukan studi randomized controlled trial prospektif untuk membandingkan efektivitas biaya fakoemulsifikasi versus SICS. Kesimpulan dari studi ini SICS menyediakan peningkatan visual dan qualityadjusted life years (QALY) yang sebanding, namun membutuhkan waktu lebih sedikit, dan secara signifikan lebih hemat biaya, dibandingkan dengan fakoemulsifikasi.

Dalam program kesehatan dengan jumlah pasien yang banyak dan terdapat keterbatasan dana, intervensi yang lebih murah dan memberikan hasil yang sama perlu dipertimbangkan sebagai alternatif pilihan. Penelitian-penelitian yang disampaikan di atas menunjukkan bahwa SICS sebanding dengan fakoemulsifikasi dalam memperbaiki tajam penglihatan pasien. Namun, teknik SICS secara signifikan terbukti dengan biaya lebih murah dengan waktu pembedahan yang lebih singkat.

Studi ini tidak dapat menggambarkan teknik mana yang paling efektif untuk pelayanan pembedahan katarak karena keterbatasan data yang didapatkan penulis. Untuk menjaga mutu dan keberlangsungan program Jaminan Kesehatan Nasional perlu dilakukan studi analisis efektivitas biaya agar didapatkan intervensi terbaik diantara alternatif yang ada, khususnya dalam pelayanan pembedahan katarak di Indonesia.

\section{Kesimpulan}

Dari analisis di atas didapatkan bahwa rerata tarif rumah sakit untuk teknik pembedahan katarak dengan SICS baik rawat jalan maupun rawat inap lebih rendah dibandingkan dengan teknik fakoemulsifikasi. Begitu pula dengan tarif INACBG pada pelayanan rawat jalan maupun rawat inap, untuk teknik fakoemulsifikasi lebih tinggi dibandingkan dengan teknik SICS. Tarif INA-CBG yang dibayarkan BPJS Kesehatan untuk kedua teknik pembedahan katarak pada pelayanan rawat jalan lebih rendah dibandingkan dengan tarif rumah sakit, namun untuk pelayanan rawat inap lebih tinggi.

\section{Saran}

Dari kesimpulan yang telah disampaikan di atas maka dapat diberikan saran untuk melakukan analisis efektivitas biaya antara teknik pembedahan SICS dan fakoemulsifikasi agar didapatkan intervensi terbaik dalam pelayanan pembedahan katarak di Indonesia. Selain itu perlu dilakukan review tarif INA-CBG dan tarif rumah sakit untuk pelayanan katarak dan diperlukan kriteria yang jelas dari organisasi profesi tentang indikasi rawat inap pasien katarak baik dengan teknik SICS maupun fakoemulsifikasi .

\section{Daftar Rujukan}

1. The International Agency for the Prevention of Blindness. South East Asia Region [Internet]. [cited 2019 Aug 1]. Available from: https:// www.iapb.org/iapb-regions/south-east-asia/

2. Kementerian Kesehatan. Pedoman Nasional Pelayanan Kedokteran Tata Laksana Katarak pada Dewasa. 2018.

3. Jongsareejit, Amporn Wiriyaluppa C, Kongsap P, Phumipan S. Cost-Effectiveness Analysis of Manual Small IncisionCataract Surgery (MSICS) and Phacoemulsification (PE). J Med Assoc Thai [Internet]. 2012; Available from: http://www.jmat.mat.or.th

4. El-Sayeda SH, El-Sobky HMK, Badawy NM, El-Shafy EAA. Phacoemulsification versus manual small incision cataract surgery for treatment of cataract. Menoufia Med J [Internet]. 2015;28:191-6. Available from: http://www. mmj.eg.net/text.asp?2015/28/1/191/155987

5. Ruit S, Tabin G, Chang D, Bajracharya L, Kline DC, Richheimer W, et al. A Prospective Randomized Clinical Trial of Phacoemulsification vs Manual Sutureless Small-Incision Extracapsular Cataract Surgery in Nepal. Am J Ophthalmol. 2007;143:32-38.

6. World Health Organization. Priority eye diseases [Internet]. [cited 2019 Aug 25]. Available from: https://www.who.int/blindness/causes/priority/ en/index $1 . h t m l$

7. BPJS Kesehatan. Efektifitas Terjaga, Mutu Tetap Prima [Internet]. Available from: https:// 
www.bpjs-kesehatan.go.id/bpjs/index.php/post/ $\mathrm{read} / 2018 / 861 /$ Efektifitas-Terjaga-Mutu-TetapPrima

8. BPJS Kesehatan. Transplantasi Ginjal Dijamin BPJS Kesehatan. Info BPJS Kesehatan - Edisi 77. 2019;12-3.

9. Pemerintah Indonesia. Peraturan Presiden RI NO 82 tahun 2018 tentang Jaminan Kesehatan. 2018.

10. Budiarto W, Sugiharto M. Biaya Klaim INA CBGs dan Biaya Riil Penyakit Katastropik Rawat Inap Peserta Jamkesmas Di Rumah Sakit Studi Di 10 Rumah Sakit Milik Kementerian Kesehatan Januari-Maret 2012. Bul Penelit Sist Kesehat. 2013;16:58-65.

11. Sari RP. Perbandingan Biaya Riil dengan Tarif Paket INA-CBG's dan Analisis Faktor yang Mempengaruhi Biaya Riil pada Pasien Diabetes Melitus Rawat Inap Jamkesmas Di RSUP Dr. Sardjito Yogyakarta [Tesis] [Internet]. Universitas Gadjah Mada; 2013. Available from: http://etd.repository.ugm.ac.id/home/ detail_pencarian $/ 59253$

12. Lewallen S, Courtright P. Gender and use of cataract surgical services in developing countries. Bull World Health Organ [Internet]. 2002;300-3. Available from: https:// www.scielosp.org/scielo.php? pid=S0042$96862002000400008 \& \mathrm{script}=\mathrm{sci}$ arttext\&tlng=en

13. Abou-Gareeb I, Lewallen S, Bassett K, Courtright P. Gender and blindness: a metaanalysis of population-based prevalence surveys. Ophthalmic Epidemiol [Internet]. 2001 Jan 1;8(1):39-56. Available from: https://doi. org/10.1076/opep.8.1.39.1540

14. Institute WE. Cataracts FAQ [Internet]. 2019 [cited 2018 Aug 24]. Available from: https:// www.hopkinsmedicine.org/wilmer/

15. Mayo Clinic. Cataract Surgery [Internet]. [cited 2019 Aug 2]. Available from: https:// www.mayoclinic.org/tests-procedures/cataractsurgery/about/pac-20384765

16. Lundström M, Barry P, Henry Y, Rosen P, Stenevi U. Evidence-based guidelines for cataract surgery: Guidelines based on data in the European Registry of Quality Outcomes for Cataract and Refractive Surgery database. J
Cataract Refract Surg. 2012;38(6):1086-93.

17. Dickson R, Eastwood A, Gill P, Melville A, O'meara S, Sheldon T. Management of cataract. Qual Heal Care [Internet]. 1996;2:180-5. Available from: http://dx.doi.org/10.1136/ qshc.5.3.180

18. Fan Z-G, Zhang D-D, Li Z-W, Yang Y, Lin X-F, $\mathrm{Zg} \mathrm{F}$, et al. Outpatient Surgery in Zhongshan Ophthalmic Center: Promise and Problems. Chin Med J (Engl). 2017;130:1623-4.

19. Holland GN, Earl DT, Wheeler NC, Straatsma BR, Pettit TH, Hepler RS, et al. Results of Inpatient and Outpatient Cataract Surgery: A Historical Cohort Comparison. Ophthalmology [Internet]. 1992;99 (6):845-52. Available from: https://doi.org/10.1016/S0161-6420(92)318822

20. Castells X, Alonso J, Castilla M, Ribó C, Cots F, Antó JM. Outcomes and costs of outpatient and inpatient cataract surgery: a randomised clinical trial. J Clin Epidemiol [Internet]. 2001;54(1):23-9. Available from: https://doi. org/10.1016/S0895-4356(00)00271-7

21. Mojon-Azzi SM, Mojon DS. The rate of outpatient cataract surgery in ten European countries: An analysis using data from the SHARE survey. Graefe's Arch Clin Exp Ophthalmol. 2007;245:1041-1044.

22. Michela Gianino M, Lenzi J, Bonaudo M, Fantini MP, Siliquini R, Ricciardi W, et al. The switch between cataract surgical settings: Evidence from a time series analysis across 20 EU countries. PLoS ONE 13(2) e0192620 [Internet]. 2018; Available from: https://doi. org/10.1371/journal.pone.0192620

23. Deepti Mahajan, Ram Lal Sharma KPC. Minimal duration cataract surgery with oblique limbal stab incision technique. Oman J Ophthamology. 2017;46(3):155-61.

24. SK. Singh, Winter I, SurinL.Phacoemulsification versus small incision cataract surgery (SICS): which one is a better surgical option for immature cataract in developing countries? Nep J Oph [Internet]. 2009;95-100. Available from: https://doi.org/10.3126/nepjoph.v1i2.3682

25. Zatila E. Evaluasi Ekonomi Operasi Katarak: Perbandingan Pendekatan Metode Manual Small Incision Cataract Surgery (MSICS) dan 
Metode Phacoemulsification di Klinik Spesialis Mata di Kota Palembang tahun 2008 [Tesis]. Universitas Indonesia; 2008.

26. NOVARI S. Analisis Biaya Satuan Tindakan Fakoemulsifikasi Tanpa Penyulit pada Operasi Katarak dengan Metode Activity Based Costing (ABC)di RSUD Dr. Achmad Mochtar Bukittinggi Tahun 2016. [Skripsi] [Internet]. Universitas Andalas; 2017. Available from: http://scholar.unand.ac.id/28687/

27. Rahma CM. Kesesuaian Biaya Rill Dengan Tarif Paket INA CBG's dan Analisis Faktor yang Berpengaruh pada Biaya Rill Pasien Operasi Katarak di Rumah Sakit Khusus Mata Provinsi Sumatera Selatan [Skripsi] [Internet]. Universitas Sriwijaya; 2019. Available from: repository.unsri.ac.id/2621/

28. Khan A, Amitava AK, Rizvi SAR, Siddiqui Z, Kumari N, Grover S. Cost-effectiveness analysis should continually assess competing health care options especially in high volume environments like cataract surgery. Indian $\mathrm{J}$ Ophthalmol. 2015;

29. Jaggernath J, Parikshit G, Moodley V, Naidoo KS. Comparison of cataract surgery techniques: Safety, efficacy, and costeffectiveness. Eur J Ophthalmol [Internet]. 2013;24 (4):520-6. Available from: https:/www.researchgate.net/ publication/259456383

30. Khanna R, Kaza S, Ghanshyam PSS,
Sangwan V. Comparative Outcomes Of Manual Small Incision Cataract Surgery And Phacoemulsification Performed By Ophthalmology Trainees In A Tertiary Eye Care Hospital In India: A Retrospective Cohort Design. BMJ Open [Internet]. 2012;2:e00103. Available from: http://dx.doi.org/10.1136/ bmjopen-2012-001035

31. Zhang J, Feng Y, Cai J. Phacoemulsification versus manual small-incision cataract surgery for age-related cataract: meta-analysis of randomized controlled trials. Clin Exp Ophthalmol [Internet]. 2013;41:379-386. Available from: https://doi.org/10.1111/j.14429071.2012.02868.x

32. Nanta AM. Perbandingan Tajam Penglihatan Pasca Operasi Katarak Senilis dengan Teknik Phacoemulsification dan Small Incision Cataract Surgery di BLUD Rumah Sakit Umum Dr. Zainoel Abidin Banda Aceh [Skripsi] [Internet]. Universitas Syiah Kuala; 2013. Available from: https://etd.unsyiah.ac.id/baca/ index.php?id $=18203 \&$ page $=10$

33. Haripriya A, Chang DF, Reena M, Madhu Shekhar. Complication rates of phacoemulsification and manual small-incision cataract surgery at Aravind Eye Hospital. J Cataract Refract Surg [Internet]. 2012;38:13601369. Available from: https://doi.org/10.1016/j. jcrs.2012.04.025 